\title{
Fen Eğitimi Kapsamında Sekizinci Sınıf Öğrencilerinin Ortaöğretime Geçiş Sınav Sistemi Değişiklikleri Hakkındaki Görüşleri ${ }^{1}$
}

\author{
Dr. Fatih ŞEKER* \\ İzmir Bakırçay Üniversitesi, İzmir / Türkiye, \\ sekerrfatih@gmail.com, ORCID: 0000-0003-0427-9208 \\ Prof. Dr. Hakan SERT \\ Akdeniz Üniversitesi, Eğitim Fakültesi, Fen Bilgisi Eğitimi, Antalya / Türkiye, \\ hsertakdeniz.edu.tr, ORCID: 0000-0001-8912-0268
}

\section{$\ddot{O} z$}

$\mathrm{Bu}$ çalışmanın amacı, ortaöğretim sınav sistemine geçiş değişikliğin sekizinci sınıf öğrencilerinin fen bilgisi dersi için kaygı, motivasyon ve başarı düzeylerini nasıl etkilediğini, öğrencilerin fen bilimleri ders başarısının ölçülmesinde hangi soru türünü tercih ettiği ve ortaöğretime geçiş sisteminin öğrencilere göre nasıl olması gerektiğini belirlemektir. Araştırmanın amacına uygun olarak kullanılan yöntem betimsel tarama modelidir. Araştırma, İstanbul'un Küçükçekmece ilçesinde bulunan alt, orta ve üst sosyoekonomik çevrede yer alan beş resmî ilköğretim okulunda öğrenim gören 607 sekizinci sınıf öğrencisi ile yürütülmüştür. Veriler açık uçlu soruların yer aldığı görüş

\footnotetext{
${ }^{1} \mathrm{Bu}$ çalışma " $5^{\text {th }}$ International Eurasian Educational Research Congress"de bildiri olarak sunulmuştur.

* Sorumlu Yazar. Tel: +90 (232) 4930000

Makale Tarih Bilgisi. Gönderim: 31.10.2019, Kabûl: 23.11.2019, Basım: Haziran, 2021

(C) 2021. Kalem Eğitim ve Sağlık Hizmetleri Vakfı. Bütün Hakları Saklıdır. ISSN: 2146-5606, e-ISSN: 2687-6574.
} 
belirleme formu ile toplanmıştır. Elde edilen veriler içerik analiz tekniği ile çözümlenmiştir. Araştırma sonucunda ortaöğretime geçiş sınav sistemindeki değişikliğin öğrencilerin \%62.8'i fen bilimlerine yönelik kaygısını arttırdığını, \%57.7'si fen bilimlerine yönelik motivasyonunu ve \%48.6'sı başarısını düşürdüğünü belirtmiştir. Buna karşın ortaöğretime geçiş sınav sistemindeki değişikliğin öğrencilerim kaygı, motivasyon ve başarı düzeylerini olumlu yönde etkilediğini ifade eden öğrencilerin oranı \%10'u geçmemektedir. Fen dersi başarılarının ölçülmesinde, ilköğretimdeki sekizinci sınıf öğrencilerinin \%90.6'sı çoktan seçmeli, \%6.3 açık uçlu ve \%3.1 çoktan seçmeli ve açı uçlu soru kullanmayı tercih edeceklerini belirtmiştir. Yeni sınav sisteminin nasıl olması gerektiği konusunda öğrencilerden elde edilen sonuçlara göre, en yüksek oranın TEOG sistemine sahip olmak, çoktan seçmeli sorulara sahip olmak, düzeltme faktörüne sahip olmamak, not ortalamasına sahip olmak ve merkezî sınav olmak olduğu belirlenmiştir.

Anahtar Kelimeler: Fen eğitimi; Ortaöğretime geçiş sınav sistemi; Kaygı; Motivasyon; Başarı.

\title{
The Opinions of $8^{\text {th }}$ Grade Students Related to Changes
}

\author{
in the Transition to Secondary Education Exams within
}

\author{
the Scope of Science Education
}

\begin{abstract}
The aim of this study is to determine how the change in the transition to secondary education exam system affects $8^{\text {th }}$ grade students' anxiety, motivation and achievement levels for science lesson, which type of question students prefer to measure the success of science course and how the transition system to secondary education should been according to the students. The method used in accordance with the aim of the study is descriptive survey model. The study was conducted with 607 $8^{\text {th }}$ grade students attending five public primary schools in the lower, middle and upper socio-economic environment in the Küçükçekmece district of İstanbul. The data were collected with an opinion determination form which included open-ended questions. As a data collection tool, an opinion determination form consisting of open-ended questions developed by the researchers was used. The data were analyzed by content analysis technique. As a result of the research, it was determined that the change in the transition system to secondary education, $62.8 \%$ of the students increased their anxiety, $57.7 \%$ stated that their motivation and $48.6 \%$ decreased their success towards science. In spite of that the rate of students who stated that the change in the transition system to secondary education positively affected their anxiety, motivation and achievement levels does not exceed $10 \%$. In the measurement of
\end{abstract}


science course achievements $90.6 \%$ of the $8^{\text {th }}$ grade students in primary education stated that they would prefer to use multiple-choice question, $6.3 \%$ open-ended question and 3.1\% multiple-choice and open-ended question. According to the results obtained from the students about how the new examination system should be, it was determined that the highest rate is to having TEOG system, having multiple choice questions, not having correction factor, having a grade point average and having a central exam.

Keywords: Science education; Transition to secondary education exam system; Anxiety; Motivation; Success.

\section{Extended Summary}

\section{Purpose}

In Turkey, transition system to secondary and higher education levels in education is always an investigated for find a best. Changes in the transition system to secondary education, such as the eliminate of exams and replacing them with a different system, make students anxious, reduce their motivation, cause them to become pessimistic and experience adaptation problems. Problems experienced in the quality of education are continuously discussed and included in the agenda in the Turkey like other countries (Can, 2014). In particular, studies are progress on the development of educational programs and the transition between levels. However, when all stakeholders, such as academics, teachers, parents and students are not taken enough their opinions, the desired achievements in the education system cannot be achieved, decisions or systems adopted are changed in a short time and new implementation is being initiated (Aykaç and Atar, 2014; Eroğlu and Özbek, 2017). Therefore, it is important to investigate the views of the stakeholders in the system in order to provide maximum benefit to the education system (Gündoğdu, Kızıltaş and Çimen, 2010). In this study, the effects of the changes in the central examination system on students' opinions related to science course were investigated. The aim of this study is to determine how the change in the transition to secondary education exam system affects $8^{\text {th }}$ grade students' anxiety, motivation and achievement levels for science lesson, which type of question students prefer to measure the success of science course and how the transition system to secondary education should been according to the students.

\section{Method}

In the study was conducted with descriptive survey method to determine the opinions of $8^{\text {th }}$ grade students. The descriptive survey model is an approach that aims to describe a situation that exists in the past or present 
(Erkuş, 2009; Karasar, 2009). After the eliminated of TEOG (Transition from Secondary to High School Education), the study was conducted with 607 volunteer $8^{\text {th }}$ grade students attending five official primary schools located in the lower, middle and upper socio-economic environment in the district of Küçükçekmece, İstanbul. The data obtained from the interviews were coded into shape of themes and analyzed according to the content analysis technique.

\section{Results}

According to the students' opinions about the changes in the secondary education transition system, it was determined that more than half of the students' motivation decreases, anxiety levels increase and nearly half of the students' achievements decreased. In the measurement of science course achievements $90.6 \%$ of the $8^{\text {th }}$ grade students in primary education stated that they would prefer to use multiple-choice question, $6.3 \%$ open-ended question and $3.1 \%$ multiple-choice and open-ended question. According to the results obtained from the students about how the new examination system should be, it was determined that the highest rate is to having TEOG system, having multiple choice questions, not having correction factor, having a grade point average and having a central exam.

\section{Discussion and Conclusion}

Within the scope of the research there are five hypotheses. The first problem of the study is "How does the change in the transition system to secondary education affect the $8^{\text {th }}$ grade students' anxiety about science?" were asked. When the findings are examined, $62.8 \%$ of the students stated that their anxiety towards science increased, $36.7 \%$ did not change and $0.5 \%$ stated that anxiety level decreased. This finding is showed that changes in the transition system to secondary education increase students' anxiety levels. The students stated that the increase in anxiety was mostly due to the uncertainty of the examination system, the difficulty of the examination, the open-ended questions in the examination, the change of the examination system and the uncertainty of the subjects. There are also studies supporting this result (Bakırc1 and Kırıc1, 2018; Demirbilek and Levent, 2019; Ormanc1, Çepni and Ülger, 2018; Uzoğlu, Cengiz and Daşdemir, 2013). The second problem of the study is "How does the change in the transition to secondary education affect the motivation of $8^{\text {th }}$ grade students towards science?" were asked. When the answers were analyzed, $57.7 \%$ of the students stated that the motivation decreased, $33.2 \%$ stated that the motivation did not change and $9.1 \%$ stated that the 
motivation increased towards science. Among the reasons for the decrease in motivation of primary school students, the categories with the highest rates are to the uncertainty of the examination system, the continuous change of the examination system, the possibility of the next exam is difficult. There are also studies parallel to this result (Bakırc1 and Kırıc1, 2018; Demirbilek and Levent, 2019; Kahraman, 2014; Özen and Özenç, 2017; Uzoğlu, Cengiz and Daşdemir, 2013). The third problem of the study is "How does the change in the transition system to secondary education affect the achievement of science in $8^{\text {th }}$ grade students?" were asked. When the answers were analyzed; because of the changes in the secondary education examination system, $48.6 \%$ of the students stated that their success decreased, $44.4 \%$ stated that their success did not change and $8 \%$ stated that their success increased. Demirbilek and Levent (2019) stated that the change in the transition between grades and examination system and central examination system decreased the success of the students. Similarly, in the study of Özen and Özenç (2017), it was determined that the changes made in the transition system to secondary education prevented the success of the students. These situations are in line with the findings of the study. The fourth problem is "What type of question does $8^{\text {th }}$ grade students prefer for the achievement in the science course?" were asked. When the answers were analyzed, it was determined that a great majority $(91 \%)$ of the $8^{\text {th }}$ grade students in primary education preferred the type of multiple-choice question. In the study conducted by Y. Kuzu, O. Kuzu and Gelbal (2019) with $8^{\text {th }}$ grade students, $77.7 \%$ of the students participated in the formation of multiple-choice questions in the transition to secondary education in the survey. Asking open-ended questions in measuring the achievement of science will be able to measure higher level thinking skills of students. Therefore, it is recommended to use different types of questions. The fifth problem is "How should be the transition system to secondary education according to the $8^{\text {th }}$ grade students in primary education?" were asked. When the answers were analyzed, it was determined that the highest rate are to having TEOG system, having multiple choice questions, not having correction factor, having a grade point average and having a central exam system. There are also studies supporting this result (Güler, Arslan and Çelik, 2019; Ormancı, Çepni and Ülger, 2018; Şad and Şahinler, 2016; Kuzu, Kuzu and Gelbal, 2019).

\section{Giriş}

Eğitim bir sistemdir. Sistemin nasıl girdisi, süreci, çıtısı ve geri bildirim mekanizmaları varsa eğitimin de vardır. Sınavlar, dünyanın her yerinde 
eleştirileri altında da olsa öğrenci, veli ve okula, eğitim sisteminin her ögesi ve özellikle sonuçları ile geri bildirim sağlamanın en etkili yollarından biridir. Sınavlar sayesinde öğrenci hakkında doğru karar verilebilmektedir. Kısacası eğitim varsa sonuçlarının sınanması da kaçınılmaz olmaktadır (Büyüköztürk, 2016). Sınav uygulamaları bireyde ön görülen kazanımların ne kadarının gerçekleştiğinin belirlenmesini ve bireyin sınavlardan aldığ puanlar sonucunda bir üst eğitim kurumuna geçmesini yani kademeler arası geçişini sağlamaktadır (Duban ve Arısoy, 2017). Türkiye'de geçmişten günümüze kademeler arası geçiş sınavları ve sistemleri üzerine sürekli bir arayış söz konusudur. Ortaöğretime geçişte sinav faktörü, 1950'li y1llardan sonra etkisini göstermeye başlamıştır. Bu süre zarfında milyonlarca öğrenci ortaöğretim geçiş sınavına girmiştir (Demirbilek ve Levent, 2019). Bu tarz sınavların uygulanmasının nedeni, eğitim sisteminde yer alan programların farklı düzeyde olması ya da istenilen eğitim kurumuna başvuru yapan adayların o eğitim kurumunda öğrenim görecek öğrenci sayısından fazla olmasıdır (Atila ve Özeken, 2015; Güzeller, 2006). Türkiye'de okul türleri arasında eğitimin niteliği, okul imkanları, saygınlık vb. durumlar açısından farklılıklar olduğu sürece, eğitim kalitesi yüksek olan okullara olan talep artacak ve talep gören okulların kapısında yığılmalar meydana gelecektir. Benzer bir durum üniversiteye geçişte de görülmektedir. Bu durum arz-talep dengesizliğine yol açmaktadır. Bu dengesizlik kademeler arası geçişte seçme ve yerleştirmeyi kaçınılmaz hâle getirmektedir (Atılgan, 2018). Kademeler arası geçişte yapılan merkezî sınavlar hem eğitimin kalitesinin arttırılmasını hem de bireylerin niteliklerine göre seçme ve yerleştirme yapılmasını amaçlamaktadır (Uğurel, Moralı ve Kesgin, 2012). Türkiye'de ortaöğretim kurumlarına seçme ve yerleştirme yapmak için geçmişten günümüze çeşitli sınav sistemleri uygulanmaktadır. Bu sınavların öğrencilerin gelecekleri açısından önemli bir yere sahip olduğu bilinmektedir. Çünkü hem öğrenciler hem de ebeveynler iyi bir ortaöğretimin kurumunun iyi bir üniversitenin kapısı olduğuna, iyi bir üniversitenin de seçkin bir mesleğe sahip olmada kilit rol oynadığına inanmaktadır (Delil ve Yolcu-Tetik, 2015; Sariyer, 2010).

Eğitim sistemindeki değişikliğe bağlı olarak merkezî sınav sistemlerinde de farklılaşmalar meydana gelmektedir. Bu farklılaşmanın sebepleri arasında; öğrenci ve ebeveynlerin kaygı düzeylerinin azaltılması, öğrencilerin etüt veya dershane gibi okul dışı merkezlere olan eğilimin azaltılması ve öğrencilerin öğrenmesi ile hayata hazırlanmasından ziyade sınava hazırlanması yer almaktadır (Uzoğlu, Cengiz ve Daşdemir, 2013). Türkiye'de de 2017- 
2018 eğitim-öğretim yılı başında temel eğitimden ortaöğretime geçiş (TEOG) sisteminin kaldırılması gerektiği ve yerine sınavsız ortaöğretime geçiş çalışması yapıldığı ifade edilmiştir (Bakırcı ve Kırıc1, 2018). Ortaöğretime geçişteki sistemlerin veya sinavların kaldırılması ve buna müteakip farklı sınav veya sistemin uygulamaya konulması gibi değişiklikler, sınava giren öğrencileri kaygılandırmakta, onların motivasyonlarını düşürerek karamsarlığa düşmelerine ve uyum sorunu yaşamalarına neden olmaktadır (Uzoğlu, Cengiz ve Daşdemir, 2013).

Temel eğitimden ortaöğretime geçiş için yapılan sınavda Türkçe, matematik gibi derslerde olduğu gibi fen bilimleri dersi konularına uygun sorular da yer almaktadır (Ormanc1, Çepni ve Ülger, 2018). Fen bilimleri dersi mihver derslerden birisi olup öğrenciyi modern hayata hazırlamaktadır (Heras ve Ruiz-Mallén, 2017; Y1lmaz, 2007). Fakat modern hayata hazırlanmaktan daha çok ortaöğretime geçiş için merkezî sınavlara hazırlanan bireylerin aileleri, onlardan sınav ile ilgili yüksek düzeyde olumlu sonuç elde etmelerini istemektedir. $\mathrm{Bu}$ istek öğrenci üzerinde baskı oluşturmaktadır ve bununla birlikte öğrencinin motivasyonu düşmekte, kaygı düzeyi de yükselmektedir (Başol ve Zabun, 2014). Kayg1, istenmedik bir durum ya da olayın gerçekleşmesi esnasında bireyin endişe yaşaması ve merkezî sinir sisteminin uyarılması durumudur (Güzeller ve Doğru, 2012). Motivasyon, bireyi olumlu ya da olumsuz bir davranışa yönlendiren istek olarak tanımlanabilir. Ayrıca motivasyon bireydeki davranışı gerçekleştirmeye yönelik isteğin kararlılığını ve enerjisini ortaya çıkarmada önemli rol oynayan duygusal bir etkendir. Motivasyonu fen bilimleri dersi açısından değerlendirildiğinde, bu derse yönelik motivasyonu yeterli olmayan bireylerin amaçlarına ulaşmada hevesli olmadıkları bilinmektedir. Bu durum da performanslarını yani başarılarını olumsuz etkilemektedir (Yılmaz ve Huyugüzel-Çavaş, 2007). Genel olarak motivasyon ve kaygı düzeyleri bireylerin başarısını farklı şekillerde etkilemektedir.

Dünyada olduğu gibi Türkiye'de de eğitimin niteliğinde yaşanan problemler sürekli olarak gündemde yer almakta ve tartışılmaktadır. Türkiye'deki eğitim sisteminin niteliğinin artması ve uluslararası seviyeye ulaşması için yoğun çabalar sürmektedir (Can, 2014). Özellikle eğitim programlarının geliştirilmesi ve kademeler arası geçişlerin nasıl olacağı yönünde çalışmalar devam etmektedir. Akademisyenler, öğretmenler, veliler ve öğrenciler gibi tüm paydaşların yeterince görüşleri alınmadığı zaman eğitim sisteminde istenilen başarılar sağlanamamakta, alınan kararlar veya getirilen sistemler kısa sürede 
değiştirilmekte ve yeni uygulamaya geçilmektedir (Aykaç ve Atar, 2014; Eroğlu ve Özbek, 2017). Dolayısyla eğitim sisteminin mevcut işleyişinin pozitif yönde ivme kazanabilmesi için sisteminde yer alan bütün dinamiklerin dikkate alınması, hedeflenen üst düzey iyileşmenin gerçekleşmesi açısından oldukça önemlidir (Gündoğdu, Kızıltaş ve Çimen, 2010). Merkezî sınav sisteminde öğrenciler, öğretmenler ve veliler çeşitli sorunlar ile karşılaşmaktadır. Bununla birlikte ortaöğretime geçiş sınav sisteminde yaşanan değişiklikler bütün paydaşları etkilemektedir. Özellikle bu değişiklikler ilköğretim seviyesinden ortaöğretim seviyesine geçecek olan bir milyonu aşan öğrenciyi doğrudan etkilemektedir (Taşkın ve Aksoy, 2018). Dolayısıyla ortaöğretim sınav sistemine ve sistemde meydana gelen değişikliğe ilişkin öğrenci görüşlerinin belirlenmesi; sistemin, ana ögesinden biri olan öğrenciler üzerinde nasıl bir etkiye sahip olduğunu anlamak açısından önemlidir (Öztürk ve Aksoy, 2014).

Alanyazın incelendiğinde Türkiye'de uygulanan ortaöğretim geçiş sistemi ve sınavlarına ilişkin görüş belirlemede; Ocak, Akgül ve Yıldız (2010) altınc1 ve yedinci sınıf öğrencilerin ortaöğretime geçiş sistemine yönelik görüşlerini, Öztürk ve Aksoy (2014) yeni ortaöğretime geçiş sınav sistemine ilişkin sekizinci sınıf öğrencilerin görüşlerini, Karaca, Bektaş ve Öner Armağan (2015) Fen Bilimleri Öğretim Programında yer alan fakat ortaöğretime geçiş sınav sisteminde sorulmayan fen konularına karşı sekizinci sınıf öğrencilerin görüşlerini incelemiştir. Özkan ve Karataş (2016) ortaöğretime geçiş sınavında yapılan değişikliğin analizini sekizinci, dokuzuncu, onuncu, on birinci ve on ikinci sınıf öğrenci görüşlerine göre değerlendirmiştir. Duban ve Arısoy (2017) ortaöğretim geçiş sınavından birisi olan TEOG'a yönelik sekizinci s1nıf öğrencilerin algılarını incelemiştir. Bununla birlikte ortaöğretim geçiş s1nav sistemine ilişkin öğretmen (Atila ve Özeken, 2015; Bakırcı ve Kırıc1, 2018; Dinç, Uzun ve Çoban, 2014; Güler, Arslan ve Çelik, 2019; Ormanc1, Çepni ve Ülger, 2018; Uzoğlu, Cengiz ve Daşdemir, 2013), veli (Demir ve Yılmaz, 2019), okul yöneticisi (Demirbilek ve Levent, 2019), hem öğretmen hem de öğrenci (Batur, Başar ve Şaşmaz, 2016; Gündoğdu, Kızıltaş ve Çimen, 2010; Özkan ve Özdemir, 2014; Şahin, Uz-Baş, Sucuoğlu, ve Şahin-Fırat, 2012; Taşkın ve Aksoy, 2018) ile öğrenci, öğretmen ve veli (Kuzu, Kuzu ve Gelbal, 2019) görüşlerini inceleyen çalışmalar da yer almaktadır. Alanyazında yapılan çalışmalar incelendiğinde çalışmaların genelinin ortaöğretim sınav sistemine ilişkin görüş belirlemeye yöneliktir. Bu çalışmada ise merkezî sınav sistemindeki değiş̧ikliğin fen bilimleri dersi ile ilgili öğrencilerin görüşleri üzerindeki yansımalarının neler olacağı araştırılmıştır. Bu nedenle çalışmanın 
özgün olduğu ve alana katkı sağlayacağı düşünülmektedir.

Çalışmanın amacı ortaöğretim sınav sistemine geçiş değişikliğin sekizinci sınıf öğrencilerinin fen bilgisi dersi için kaygı, motivasyon ve başarı düzeylerini nasıl etkilediği, öğrencilerin fen bilimleri ders başarısının ölçülmesinde hangi soru türünü tercih ettiği ve ortaöğretime geçiş sisteminin öğrencilere göre nasıl olması gerektiğini belirlemektir. Bu kapsamda aşağıdaki sorulara yanıt aranmıştır:

1. Ortaöğretime geçiş sınav sistemindeki değişikliğin ilköğretim sekizinci sınıf öğrencilerin fen bilimlerine yönelik kaygısını nasıl etkilemektedir?

2. Ortaöğretime geçiş sınav sistemindeki değişikliğin ilköğretim sekizinci sınıf öğrencilerin fen bilimlerine yönelik motivasyonunu nasıl etkilemektedir?

3. Ortaöğretime geçiş sınav sistemindeki değişikliğin ilköğretim sekizinci sınıf öğrencilerin fen bilimleri başarısını nasıl etkilemektedir?

4. İlköğretim sekizinci sınıf öğrencilerin fen bilimleri başarısının ölçülmesinde hangi soru türünü tercih etmektedir?

5. İlköğretim sekizinci sınıf öğrencilerine göre ortaöğretime geçiş sınav sistemi nasıl olmalıdır?

$\mathrm{Bu}$ araştırmanın sınırlılığı ise TEOG sınavının kaldırılmasından hemen sonra, yeni sistemin ne olacağı açıklanmadan verilerin toplanmasıdır.

\section{Yöntem}

\section{Araștırma Modeli}

Araştırma, ortaöğretime geçiş sınav sistemindeki değişikliğin ilköğretim sekizinci sınıf öğrencilerin fen bilimlerine yönelik kaygı, motivasyon ve başarı düzeyini nasıl etkilediği ile fen bilimleri başarısının ölçülmesinde hangi soru türünü tercih ettiği ve ortaöğretime geçiş sınav sisteminin nasıl olmas1 gerektiğine dair görüşünü belirlemeye yöneliktir. Bu nedenle çalışma, sekizinci sınıf öğrencilerin görüşleri belirlemek için betimsel tarama yöntemi ile yürütülmüştür. Betimsel tarama yönteminde özellikle aniden meydana gelen herhangi bir gelişmeden sonra o doğal değişime maruz kalan grubun görüşlerini ve davranışlarını belirlemeye dayanır. Betimsel tarama modeli, şu an veya geçmişteki herhangi bir durumu var olduğu hâliyle betimlemeyi amaçlamaktadır (Erkuş, 2009; Karasar, 2009). Bu yaklaşım doğrultusunda, ortaöğretime geçiş sınav sistemindeki değişikliğin ilköğretim sekizinci sınıf öğrencilerinin 
belirlenmesi sebebiyle mevcut durum betimlenmeye çalışılmıştır.

\section{Çalışma Grubu}

Araştırma 2018-2019 eğitim-öğretim yılı içerisinde TEOG merkezî s1nav sisteminin kaldırılmasından sonra İstanbul ili Küçükçekmece ilçesinde bulunan alt, orta ve üst sosyoekonomik çevrede bulanan beş resmi ilköğretim okulunda öğrenim gören 607 gönüllü sekizinci sınıf öğrencisi ile yürütülmüştür. Çalışma grubunda yer alan öğrencilerin 127'si (\%20.65) alt, 268'i (\%43.57) orta ve 220'si (\%35.77) üst sosyoekonomik çevrede bulunan okulun öğrencileridir.

\section{Veri Toplama Araçları}

Veri toplama aracı olarak araştırmacılar tarafından geliştirilen ve sekizinci sınıf öğrencilerinin yazılı görüşlerinin alınmasını sağlayan "Yapıland1rılmamış Görüş Belirleme Formu” kullanılmıştır. Görüş belirleme formu iki bölümden oluşmaktadır. İlk bölüm demografik özelliklerden ikinci bölüm ise 5 açık uçlu sorudan oluşmaktadır. Açık uçlu sorulardan ilk üçü sekizinci sınıf öğrencilerin merkezî sınav sistemi değişikliğinin fen bilimleri dersine yönelik kaygı, motivasyon ve başarısını nasıl etkilediği; diğer sorular fen bilimleri başarısının ölçülmesinde öğrencilerin hangi soru türünü tercih ettiği ve ortaöğretime geçiş sınav sisteminin nasıl olması gerektiği ile ilgilidir. Formun hazırlık merhalesinde alanyazın taraması yapılmıştır. İlköğretim sekizinci sınıf öğrencilerinden oluşan 35 kişiye formun ön uygulaması yapılmıştır. İlk uygulama sonucunda öğrencilerden alınan dönütler göz önünde bulundurularak gerekli düzenlemeler yapılmış ve alan uzmanları tarafından değerlendirilmiştir. $\mathrm{Bu}$ sayede görüş belirleme formunun geçerliliği ve güvenirliliği sağlanmıştır. Son şeklini alan görüş belirleme formu çoğaltılarak bizzat araştırmacılar tarafından dersin öğretmeni eşliğinde sınıfta uygulanmıştır. Araştırmacılar ve ders öğretmeni formun uygulanması için gerekli koşulları ve motivasyonu sağlamıştır. Araştırmacılar yapılan çalışma hakkında kısa bilgilendirme yapmış ve öğrencilerin sordukları sorulara yönlendirme yapmadan açıklama yapmıştır.

\section{Veri Analizi}

Sekizinci sınıf öğrencilerinin yazılı görüşlerinden elde edilen verilerin çözümlenmesi, içerik analiz tekniğine göre yapılmıştır. İçerik analiz tekniğinde genel amaç birbirine benzeyen verileri belirli tema ve kavramlara göre bir araya getirmek ve anlaşabilir düzeyde yorumlamaktır. Bu araştırmada veriler için kategoriler ve kodlar oluşturulmuştur. Araştırmada iç geçerliğin arttırılması açısından ana tema, alt tema ve bütün temalar arasında bütünlük 
oluşturulmasına dikkat edilmiştir (Yıldırım ve Şimşek, 2008). Araştırmacılar tarafindan kodlanarak oluşturulan temalarda birinci, ikinci ve üçüncü sorulara yönelik "Düştü, Değişmedi ve Yükseldi” olarak gruplandırma yapılmış daha sonra nedenlerine yer verilmiştir. Dördüncü ve beşinci sorulara yönelik olarak ise farkl1 temalar oluşturulmuştur. Genel olarak oluşturulan temalar, tema bulamama veya birden fazla bilgilendirme gibi nedenlerden dolayı araştırmaya katılan her bir öğrenci yerine, analize uygun tema bildiren öğrenci sayısına göre oluşturulmuştur. Bu nedenle sorulara verilen cevapların analiz işleminde öğrenci sayısı değil öğrenci görüş yüzdesi dikkate alınmıştır.

\section{Bulgular}

$\mathrm{Bu}$ araştırma sonucunda elde edilen bulgular belirli kategorilere göre gruplandırılıp yüzde (\%) ve frekans (f) cinsinden ifade edilmiş, grafik ve tablo hâlinde sunularak analiz sonuçlarına dayalı yorumlar yapılmıştır. Öğrencilere uygulanan görüş belirleme formu aracılığıyla ortaöğretime geçiş sınav sistemindeki değişikliğin öğrencilerin görüşlerine göre belirleneceği düşüncesiyle bu şekilde bir çalışma yolu izlenmiştir. Öğrencilere "Sizce SBS, TEOG gibi ortaöğretime geçiş sınav sisteminin değişmesi; sırasıyla fen bilimleri dersine yönelik kaygı, motivasyon ve akademik başarınızı nasıl etkilemektedir? Nedenini açıklayınız." şeklinde üç farklı soru yöneltilmiştir. Sorulardan elde edilen cevaplar analiz edildiğinde ortaya çıkan temalar Grafik 1'de sunulmuştur.

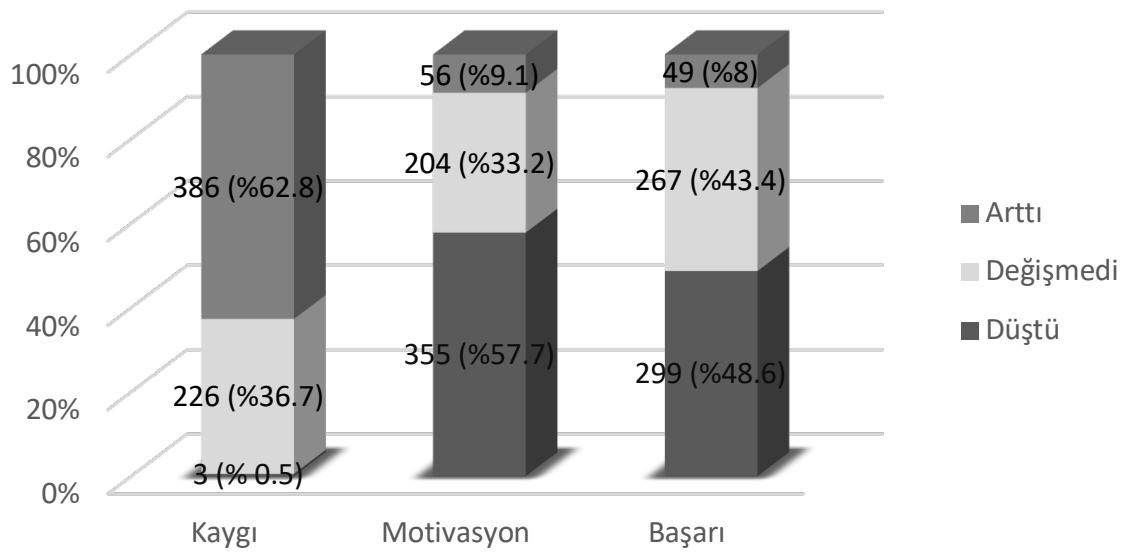

Grafik 1. Ortaöğretime Geçiş Sınav Sisteminin Değişmesinin İlköğretim Sekizinci Sınıf Öğrencilerinin Fen Bilimlerine Yönelik Kaygı, Motivasyon ve Başarısını Nasıl Etkilediğine Dair Frekans ve Yüzde Dağılımı

Sekizinci sınıf öğrencilerin görüşlerine göre, merkezî sınav sistemi 
değişikliğinin fen bilimleri dersine yönelik kaygı, motivasyon ve başarıya ait görüş belirleme formu analiz edildiğinde düştü, değişmedi ve arttı kategorileri oluşturulmuştur. Grafik 1 incelendiğinde, ortaöğretime geçiş sınav sisteminin değişmesinin öğrencilerin yarısından fazlasının fen bilimleri dersine yönelik motivasyonlarının düştüğü ve kaygı düzeylerinin arttığı görüşü ile öğrencilerin yarısına yakınının fen bilimleri dersine yönelik başarılarının düştüğü görüşü tespit edilmiştir. Buna karşın ortaöğretime geçiş sınav sistemi değişikliğinin öğrencilerin \%9.1'i fen bilimleri motivasyonunu ve \%8'i başarısını artırdığını \%0.5'i ise kaygısını azalttığını belirtmiştir.

Veriler içerik analizi yapıldıktan sonra ortaöğretime geçiş sınav sistemi değişikliğinin ilköğretim sekizinci sınıf öğrencilerin fen bilimlerine yönelik kaygı düzeylerini etkileme nedenlerine ait kategoriler ile kategorilere ait frekans ve yüzdeler Tablo 1'de sunulmuştur.

Tablo 1. Ortaöğretime Geçiş Sınav Sistemi Değişikliğinin Öğrencilerin Fen Bilimlerine Yönelik Kaygı Düzeylerini Etkileme Nedenlerine Ait Kategoriler ile Kategorilere Ait Frekans ve Yüzdeler

\begin{tabular}{llll}
\hline Kategoriler & & $\boldsymbol{f}$ & $\boldsymbol{\%}$ \\
\hline Kaygının & Çalı̧̧an yapar düşüncesi & 42 & 32.8 \\
nüsme & Fen bilimlerini sevme & 26 & 20.3 \\
& Yine sınavın olması sadece adının değişmesi & 21 & 16.4 \\
& Kendine güvenme durumu & 21 & 16.4 \\
& Fen bilimlerinde başarılı olma & 9 & 7 \\
& Konuların aynı olması ve değişen bir şeyin olmaması & 3 & 2.3 \\
& Üç yanlışın bir doğruyu götürmüyor olması & 2 & 1.6 \\
& Yeni sistemin daha iyi olma durumu & 2 & 1.6 \\
& Fen bilimleri dersinin kolay olması & 1 & 0.8 \\
& Sistem değişince çalışıcak zamanın artması & 1 & 0.8 \\
& Toplam & 128 & 100 \\
\hline Kaygının & Çalışan yapar düşüncesi & 1 & 100 \\
değişmeme & Toplam & 1 & 100 \\
nedeni & Sinav sisteminin belirsiz olması & 97 & 427 \\
\hline Kaygının & Sinavın zor olma durumu & 43 & 18.9 \\
artma & Sinavda açı uçlu soruların olma ihtimali & 29 & 12.8 \\
nedenleri & Sinav sistemin değişmesi & 26 & 11.5 \\
& Sınav sisteminde hangi konuların çıkacağının belirsiz olması & 25 & 11 \\
& Önceki sınav sistemine olan alışkanlık ve önceki sınava göre & 3 & 1.3 \\
& çalışma & & \\
& Ortaöğretime geçiş sınav sistemine olan güvenin azalması & 2 & 0.9 \\
& Motivasyonun düşmesi & 2 & 0.9 \\
& Toplam & 227 & 100 \\
\hline
\end{tabular}

Öğrencilere "Sınav değişikliğinin fen bilimlerine yönelik kaygınızı nas1l etkilemektedir?" sorusu sorulduğunda öğrencilerin \%62.8'i fen bilimlerine 
yönelik kaygısının yükseldiğini, \%36.7'si değişmediğini ve \%0.5'i kaygı düzeyinin düştüğünü ifade etmiştir. Tablo 1'deki kaygı düzeyinin yükselme nedenlerine bakıldığında öğrencilerin verdikleri cevapların sırasıyla \%42.7'lik ve \%18.9'luk oranla en fazla kategorinin "sinav sisteminin belirsiz olması" ve "sınavın zor olma durumu" şeklinde olduğu görülmektedir. Buna karşın öğrencilerin kaygı düzeyinin artma nedenleri arasında en düşük oranların "önceki sınav sistemine olan alışkanlık ve önceki sınava göre çalışma (\%1.3)", "ortaöğretime geçiş sınav sistemine olan güvenin azalması (\%0.9)" ve "motivasyonun düşmesi (0.9)" yer almaktadır. Bununla birlikte kaygı düzeyinin düşme nedenlerine bakıldığında öğrencilerin verdikleri cevaplar arasında en yüksek oranın "çalışan yapar düşüncesi (\%32.8)", "fen bilimlerini sevme (\%20.3)" ve "yine sınavın olması sadece adının değişmesi (16.4)", en düşük oranın ise "fen bilimleri dersinin kolay olması (\%0.8)" ve "sistem değişince çalışılacak zamanın artması (\%0.8)" olduğu belirlenmiştir.

Ortaöğretime geçiş sınav sistemi değişikliğinin ilköğretim sekizinci s1nıf öğrencilerin fen bilimlerine yönelik motivasyon düzeylerini etkileme nedenlerine ait kategoriler ile kategorilere ait frekans ve yüzdeler Tablo 2'de verilmiştir.

Tablo 2 incelendiğinde öğrencilerin motivasyonun düşme nedenlerine ait verdiği cevaplar arasında en yüksek oranın "sınav sisteminin belirsiz olması (\%40)" ve "sınav sisteminin sürekli değişmesi (\%22)" olduğu, en düşük oranların ise "soruların değişmesi (\%1.2)", "değişikliğin öğrencilerin kendilerine denk gelmesi (\%0.8)", ve "sınav sisteminin değişmesinden kaynaklı öz güvenin azalması (\%0.4)" olduğu görülmektedir. Öğrencilerin motivasyonun artma nedenlerine ait verdiği cevaplar arasında en yüksek oranın "gelecek s1nav sisteminin zor olabilmesinden dolayı çok çalışma (\%24.1)", "sınav için sürenin artması (\%16)" ve "fen bilimlerini sevme (\%16)" olduğu, eşit frekansa sahip en düşük oranların (\%2.3) ise "aile desteğinin artması", "öğrenci hedefinin olması", "öğrencinin kayg1 ve stres yaşaması", "çalışan yapar düşüncesi”" ile "fen bilimleri dersinin kolay olması"nın olduğu görülmektedir. 
Tablo 2. Ortaöğretime Geçiş Sınav Sistemi Değişikliğinin Öğrencilerin Fen Bilimlerine Yönelik Motivasyon Düzeylerini Etkileme Nedenlerine Ait Kategoriler ile Kategorilere ait Frekans ve Yüzdeler

\begin{tabular}{|c|c|c|c|}
\hline \multicolumn{2}{|c|}{ Kategoriler } & $f$ & $\%$ \\
\hline \multirow{12}{*}{ 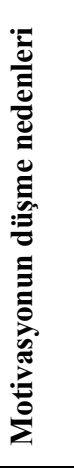 } & Sinav sisteminin belirsiz olması & 102 & 40 \\
\hline & Sınav sisteminin sürekli değişmesi & 56 & 22 \\
\hline & Yeni gelecek olan sinav sistemin zor olma ihtimali & 21 & 8.4 \\
\hline & Önceki sınav sisteme alışkın olma durumu & 20 & 8 \\
\hline & Sınav sisteminin değişmesinden dolayı stresin artması & 18 & 7 \\
\hline & Sınav sisteminde hangi konuların çıkacağının belirsiz olması & 18 & 7 \\
\hline & Açık uçlu soru türünün sınav sisteminde yer alma ihtimali & 9 & 3.6 \\
\hline & $\begin{array}{l}\text { Sınav sisteminin değişmesinden kaynaklı fen bilimlerine olan ilginin } \\
\text { azalması }\end{array}$ & 4 & 1.6 \\
\hline & Soruların değişmesi & 3 & 1.2 \\
\hline & Değişikliğin öğrencilerin kendilerine denk gelmesi & 2 & 0.8 \\
\hline & Sınav sisteminin değişmesinden kaynaklı öz güvenin azalması & 1 & 0.4 \\
\hline & Toplam & 250 & 100 \\
\hline \multirow{13}{*}{ 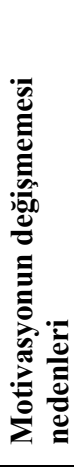 } & Fen bilimlerini sevme ve fen bilimlerine ilgi duyma & 40 & 32 \\
\hline & Çalışan yapar düşüncesi & 34 & 27.2 \\
\hline & Yine sınavın olması sadece adının değişmesi & 21 & 16.8 \\
\hline & Fen bilimlerinde başarılı olma & 7 & 5.6 \\
\hline & Başarılı olacağına inanma & 5 & 4 \\
\hline & Programlı çalışma & 4 & 3.2 \\
\hline & Konuların aynı olması ve değişen bir şeyin olmaması & 4 & 3.2 \\
\hline & Çalışma düzeninin aynı olması & 3 & 2.4 \\
\hline & Fen bilimleri dersinde devamlı başarısızlık yaşanması & 3 & 2.4 \\
\hline & Öğrenci hedefinin olması & 2 & 1.6 \\
\hline & Fen bilimlerinin deney ve gözleme dayalı olması & 1 & 0.8 \\
\hline & Fen bilimleri dersinin kolay olması & 1 & 0.8 \\
\hline & Toplam & 125 & 100 \\
\hline \multirow{12}{*}{ 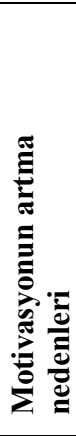 } & Gelecek sınav sisteminin zor olabilmesinden dolayı çok çalışma & 10 & 24.1 \\
\hline & Sınav için sürenin artması & 7 & 16 \\
\hline & Fen bilimlerini sevme & 7 & 16 \\
\hline & Sınav sisteminin belirsiz olmasından dolayı çok çalışma & 6 & 13.9 \\
\hline & Yeni sistem daha kolay olma ihtimali & 5 & 11.6 \\
\hline & Yine sınavın olması sadece adının değişmesi & 3 & 6.9 \\
\hline & Aile desteğinin artması & 1 & 2.3 \\
\hline & Öğrenci hedefinin olması & 1 & 2.3 \\
\hline & Öğrencinin kaygı ve stres yaşaması & 1 & 2.3 \\
\hline & Çalışan yapar düşüncesi & 1 & 2.3 \\
\hline & Fen bilimleri dersinin kolay olmas & 1 & 2.3 \\
\hline & Toplam & 43 & 100 \\
\hline
\end{tabular}

Ortaöğretime geçiş sınav sistemi değişikliğinin ilköğretim sekizinci s1nıf öğrencilerin fen bilimlerine yönelik başarı düzeylerini etkileme nedenlerine ait kategoriler ile kategorilere ait frekans ve yüzdeler Tablo 3'de sunulmuştur. 
Tablo 3. Ortaöğretime Geçiş Sınav Sistemi Değişikliğinin Öğrencilerin Fen Bilimlerine Yönelik Başarı Düzeylerini Etkileme Nedenlerine Ait Kategoriler ile Kategorilere Ait Frekans ve Yüzdeler

\begin{tabular}{|c|c|c|c|}
\hline \multicolumn{2}{|c|}{ Kategoriler } & \multirow{2}{*}{$\frac{f}{65}$} & \multirow{2}{*}{$\frac{\pi}{34.9}$} \\
\hline \multirow{8}{*}{  } & Sinav sisteminin belirsiz olmas1 & & \\
\hline & Motivasyonun düşmesi ve kaygının artması & 49 & 26.3 \\
\hline & Sinavin zor olma durumu & 21 & 11.3 \\
\hline & Sınav sisteminin sürekli değişmesi & 18 & 9.7 \\
\hline & Sınavda açık uçlu soruların olma ihtimali & 14 & 7.5 \\
\hline & $\begin{array}{l}\text { Önceki sınav sistemine olan alışkanlık ve önceki sınava göre } \\
\text { çalışma }\end{array}$ & 12 & 6.5 \\
\hline & Sınav sisteminde hangi konuların çıkacağının belirsiz olması & 7 & 3.8 \\
\hline & Toplam & 186 & 100 \\
\hline \multirow{7}{*}{ : } & Çalışan yapar düşüncesi & 76 & 48.4 \\
\hline & Konuların aynı olması ve değişen bir şeyin olmaması & 32 & 20.4 \\
\hline & Fen bilimlerinde başarılı olma & 29 & 18.5 \\
\hline & Fen bilimlerini sevme & 16 & 10.2 \\
\hline & Fen bilimleri dersinde devamlı başarısızlık yaşanması & 2 & 1.25 \\
\hline & Fen bilimleri dersinin kolay olması & 2 & 1.25 \\
\hline & Toplam & 157 & 100 \\
\hline \multirow{6}{*}{  } & Gelecek sınav sisteminin zor olabilmesinden dolayı çok çalışma & 20 & 50 \\
\hline & Sınav sisteminin belirsiz olmasından dolayı çok çalışma & 7 & 17.5 \\
\hline & Çalışan yapar düşüncesi & 7 & 17.5 \\
\hline & Motivasyonum artmas & 5 & 12.5 \\
\hline & Sistem değişince çalışılacak zamanın artması & 1 & 2.5 \\
\hline & Toplam & 40 & 100 \\
\hline
\end{tabular}

Tablo 3 incelendiğinde öğrencilerin başarısının düşme nedenlerine ait verdiği cevaplar arasında en yüksek oranın "sınav sisteminin belirsiz olması (\%34.9)" ve "motivasyonun düşmesi ve kaygının artması (\%26.3)" olduğu, en düşük oranların ise "önceki sınav sistemine olan alışkanlık ve önceki sınava göre çalışma (\%6.5)" ile "sınav sisteminde hangi konuların çıkacağının belirsiz olması (\%3.8)" olduğu görülmektedir. Öğrencilerin başarısının artma nedenlerine ait verdiği cevaplar arasında sırasıyla en yüksek oranların "gelecek sınav sisteminin zor olabilmesinden dolayı çok çalışma (\%50)" ile "sınav sisteminin belirsiz olmasından dolayı çok çalışma (\%17.5)" olduğu, en düşük oranların ise "motivasyonum artması (\%12.5)" ve "sistem değişince çalışılacak zamanın artması (\%2.5)" olduğu belirlenmiştir.

"İlköğretim sekizinci sınıf öğrencileri fen bilimleri başarısının ölçülmesinde hangi soru türünü tercih etmektedir?" sorusuna verilen cevapların analizleri Grafik 2'de sunulmuştur. 
- Çoktan seçmeli sorular $\square$ Açık uçlu sorular —Çoktan seçmeli ve açık uçlu sorular

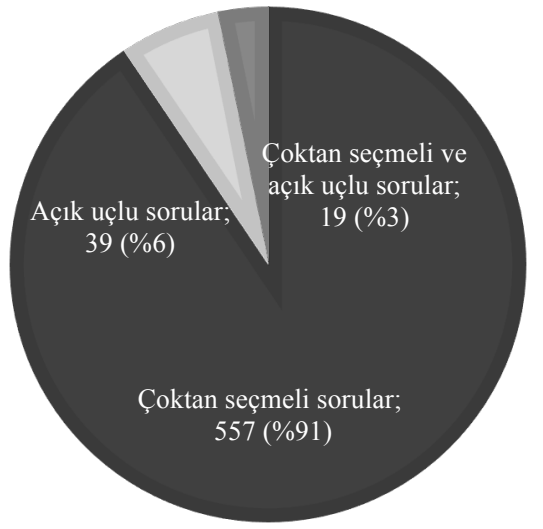

Grafik 2. İlköğretim Sekizinci Sınıf Öğrencilerin Fen Bilimleri Başarısının Ölçülmesinde Hangi Soru Türünü Tercih Ettiğine Dair Verilen Cevaplara ait Frekans ve Yüzde Dağılımı

Grafik 2 incelendiğinde, ilköğretim sekizinci sınıf öğrencilerin \%91'i fen bilimleri başarısının ölçülmesinde çoktan seçmeli, \%6'sı açık uçlu ve \%3'ü hem açık uçlu hem de çoktan seçmeli soru türünü tercih ettiği görülmektedir. Öğrencilerin çoktan seçmeli soruları tercih etme nedenleri arasında en yüksek oranların çoktan seçmeli sorularda mantık yürütebilmenin olması, şans faktörünün olması, bilgiyi hatırlamanın kolay olması ve objektif olması yer almaktadır. Öğrencilerin açık uçlu soruları tercih etmelerinin nedenleri arasında; bilgi ve başarıyı daha doğru ölçmesi, daha adaletli olması ve ayırt ediciliğinin yüksek olması yer almaktadır. Her iki soru türünü tercih edenler ise ikisinin karmasının daha başarılı bir ölçme olacağını düşünmesidir.

“İlköğretim sekizinci sınıf öğrencilerine göre ortaöğretime geçiş sınav sistemi nasıl olmalıdır?" sorusuna verilen cevapların analizleri Tablo 4'te sunulmuştur. Tablo 4'te oluşturulan kategorilerin geneline ait değerlere bakıld1ğında, ilköğretim sekizinci sınıf öğrencilerinin büyük bir çoğunluğu (\%40 ve \%33) ortaöğretime geçiş sınav sisteminin "önceki sınav sistemi gibi (TEOG) olsun" ve "çoktan seçmeli sorulardan oluşan bir sınav olsun" şeklinde görüş bildirmiştir. Diğer taraftan tablo incelendiğinde kaldırılan ortaöğretime geçiş sistemi (TEOG) ile öğrencilerin yeni ortaöğretime geçiş sınav sistemi arasında benzerliklerin olduğu görülmektedir. Bunun yanında en düşük oranlar arasında "ortaöğretime geçiş sınav sistemi 5., 6.,7., ve 8. sınıf seviyesinde her yıl yapılsın", "iyi liseler kendi sınavlarını yapsın", "sadece isteyen sınava girsin" 
ve "ortaöğretime geçiş sınavında bol görselli soru olsun" yer almaktadır.

Tablo 4. İlköğretim Sekizinci Sınıf Öğrencilerine Göre Ortaöğretime Geçiş Sinav Sistemi Nasıl Olmalıdır? Sorusuna Verilen Cevaplara Ait Frekans ve Yüzde Dağglımı

\begin{tabular}{lll}
\hline Kategoriler & f & \% \\
\hline Önceki sınav sistemi gibi (TEOG) olsun & 260 & 40 \\
Çoktan seçmeli sorulardan oluşan bir sınav olsun & 215 & 33 \\
Üç yanlışın bir doğruyu götürmediği sınav olsun & 35 & 5.4 \\
Not ortalaması etkili olsun & 29 & 4.45 \\
Merkezî bir sınav olsun & 15 & 2.3 \\
Ortaöğretime geçiş sınav sistemi adrese dayalı olsun & 13 & 2 \\
Hem merkezî bir sınavın hem de adrese dayalı olsun & 13 & 2 \\
Çoktan seçmeli ve açık uçlu sorulardan oluşan bir sınav olsun & 10 & 1.5 \\
Sınav süresi uzun olsun & 9 & 1.4 \\
Sınavsız geçişin olduğu bir sistem olsun & 9 & 1.4 \\
Ortaöğretime geçiş sınav sistemi kolay olsun & 8 & 1.2 \\
Ortaöğretime geçiş sınav sistemi sekizinci sınıfın sonunda olsun & 7 & 1.1 \\
Adaletli olsun & 7 & 1.1 \\
Açık uçlu sorulardan oluşan bir sistem olsun & 6 & 0.9 \\
Ortaöğretime geçiş öğrencilerin ilgi ve yeteneklerine göre olsun & 4 & 0.6 \\
Merkezî sınavın kapsam geçerliliği artsın & 3 & 0.5 \\
Sözel ve sayısal konular olsun & 2 & 0.3 \\
Ortaöğretime geçiş sınav orta güçlükte olsun & 2 & 0.3 \\
Ortaöğretime geçiş sınav sistemi 5, 6,7 ve 8. sınıf seviyesinde her yıl yapılsınn & 1 & 0.15 \\
İyi liseler kendi sınavlarını yapsın & 1 & 0.15 \\
Sadece isteyen sınava girsin & 1 & 0.15 \\
Ortaöğretime geçiş sınavında bol görselli soru olsun & 1 & 0.15 \\
\hline Toplam & $\mathbf{6 5 1}$ & $\mathbf{1 0 0}$ \\
\hline
\end{tabular}

\section{Tartışma ve Sonuç}

Araştırma kapsamında ortaöğretime geçiş sınav sistemindeki değişikliğin ilköğretim sekizinci sınıf öğrencilerin fen bilimlerine yönelik kaygı, motivasyon ve başarı düzeyini nasıl etkilediği ile fen bilimleri başarısının ölçülmesinde hangi soru türünü tercih ettiği ve ortaöğretime geçiş sınav sisteminin nasıl olması gerektiğine dair görüşleri belirlenmiştir.

Çalışmanın ilk probleminde ilköğretim sekizinci sınıf öğrencilerine yöneltilen "Ortaöğretime geçiş sınav sistemindeki değişikliğin ilköğretim sekizinci sınıf öğrencilerin fen bilimlerine yönelik kaygısını nasıl etkilemektedir?" sorusu yer almaktadır. Bu soruya verilen cevaplardan elde edilen bulgular incelendiğinde öğrencilerin \%62.8's1 fen bilimlerine yönelik kaygısının yükseldiğini, \%36.7'u değişmediğini ve \%0.5'i kayg1 düzeyinin düştüğünü 
ifade etmiş̧tir. Öğrencilerin yarısından fazlası ortaöğretim sınav sistemi değişikliğinden dolayı fen bilimlerine yönelik kaygı seviyesinin arttığını ifade etmiştir. Öğrenciler kaygı yükselmesinin en fazla sınav sisteminin belirsiz olmasından, sınavın zor olmasından, sınavda açık uçlu soruların olmasından, sınav sisteminin değişmesinden ve konuların belirsiz olmasından kaynaklandığını belirtmiştir. Buna karşın ortaöğretim sınav sistemi değişikliğinin öğrencilerin kaygı seviyesini düşürdügüne dair düşük oranda kategoriler tespit edilmiştir. Kaygı seviyesinin düşmesine neden olan kategoriler arasında çalışan yapar düşüncesi, fen bilimlerini sevme, yine sınavın olması, öz güven, fen bilimlerinde başarılı olma gibi kategoriler yer almaktadır. Genel olarak bu hipotez değerlendirildiğinde ortaöğretime geçiş sınav sistemi değişikliğin öğrencilerin fen bilimlerine yönelik kaygısını arttırdığı görüşü ortaya çıkmaktadır. Bakırcı ve Kırıcı (2018) TEOG'un kaldırılmasına yönelik öğretmen görüşlerini incelemiş ve öğretmenler, öğrencilerin fen bilimlerine yönelik kaygılar1nın oluştuğunu belirtmiştir. Demirbilek ve Levent (2019), yaptığı çalışmada kademeler arası geçiş sistemi ile ilgili yapılan değişikliklerin veli ve öğrencilerde kayg1, karamsarlık, güvensizlik ve yılgınlığa neden olduğunu tespit etmiştir. Ormanc1, Çepni ve Ülger (2018), ortaöğretime geçiş sınav sistemleri ile ilgili olarak fen bilimleri öğretmenlerinin görüşlerini incelemiştir. Fen bilimleri öğretmenleri ortaöğretime geçiş sisteminde yapılan değişikliklerin öğrencilerin kaygı düzeylerini arttırdığı ve bu artışın büyük oranda belirsizlikten kaynaklandığını belirtmiştir. Uzoğlu, Cengiz ve Daşdemir'in (2013) fen bilimleri öğretmenleri ile yaptığı çalışmada öğretmenlerin ortaöğretime geçiş sınav sisteminin sürekli değişmesinden dolayı endişe duyduklarını tespit etmiştir. Ayrıca sistem değişikliğinin sürekli olması öğrencilerde karamsarlık, gelecek endişesi ve kaygıya yol açtığını belirtmiştir. Özen ve Özenç'in (2017) yaptıkları çalışmada ortaöğretime geçiş sisteminde yapılan değişiklilerin öğrencilerin motivasyonlarını olumsuz etkilediğini, belirsizlikten dolayı öğrencilerin stres ve kaygı yaşadığını belirtmiştir. Bu, öğrencilerin motivasyonunu düşürmekte ve öğrencilerin başarılı olmasını törpülemektedir. Bu sonuçlar çalışmanın bulguları ile paralellik göstermektedir.

Çalışmanın ikinci probleminde öğrencilere "Ortaöğretime geçiş sınav sistemindeki değişikliğin ilköğretim sekizinci sınıf öğrencilerin fen bilimlerine yönelik motivasyonunu nasıl etkilemektedir?" sorusu yöneltilmiş ve cevaplar alınmıştır. Cevaplar analiz edildiğinde öğrencilerin \%57.7'si fen bilimlerine yönelik motivasyonun düştüğünü, \%33.2'si motivasyonun değişmediğini ve \%9.1'i ise motivasyonun arttı̆̆ını ifade etmiştir. İlköğretim 
öğrencilerinin motivasyonlarının düşme nedenleri arasında sınav sisteminin belirsiz olması, sınav sisteminin sürekli değişmesi, yeni gelecek olan sınavın zor olma ihtimali yer almaktadır. Öğrencilerin ortaöğretime geçiş sınav sistemindeki değişikliğin fen bilimleri dersine yönelik motivasyonu artma sebebi olarak ise gelecek sınav sisteminin zor olabilmesinden dolayı daha çok çalışma, sınav süresinin artması, fen bilimlerini sevme, sınav sisteminin belirsiz olması nedeniyle daha çok çalışma kategorileri en yüksek orana sahiptir. Bakırc1 ve Kırıc1 (2018), ortaöğretime geçiş sınav sisteminde meydana gelen değişikliğin öğrencilerin fen bilimleri dersine yönelik motivasyonunu düşürdüğünü belirtmiştir. Uzoğlu, Cengiz ve Daşdemir'in (2013) fen bilimleri öğretmenleri ile yaptığı çalışmada ortaöğretim geçiş sınav sisteminin sürekli olarak değişmesinin öğrencilerde motivasyon düşüklüğüne neden olduğunu belirlenmiştir. Demirbilek ve Levent'in (2019) yaptığı çalışmada okul yöneticileri, kademeler arası geçiş ve sınav sisteminde yapılan değişikliğin bilgilendirilme ve belirsizlikten kaynaklı bilgi eksikliği nedeniyle paydaşların motivasyon kaybı yaşadığını belirtmiştir. Özen ve Özenç (2017) ortaöğretime geçiş sisteminde yapılan değişiklilerin öğrencilerin motivasyonlarını düşürdüğünü belirtmektedir. Benzer şekilde Kahraman (2014) sistem değişikliği sonucunda uygulanan ilk sınavın öğrencilerin motivasyonunu olumsuz etkilediğini vurgulamaktadir.

Çalışmanın üçüncü probleminde öğrencilere "Ortaöğretime geçiş sınav sistemindeki değişikliğin ilköğretim sekizinci sınıf öğrencilerin fen bilimlerine yönelik başarısını nasıl etkilemektedir?" sorusu yöneltilmiş ve cevaplar alınmıştır. Cevaplar analiz edildiğinde ortaöğretim sınav sistemindeki değişiklikler nedeniyle öğrencilerin \%48.6's1 fen bilimlerine yönelik başarısının düştüğünü, \%43.4'ü başarısının değişmediğini ve \%8'i başarısının arttığını ifade etmiştir. Bu bulgular ışığında öğrencilerin yarısına yakını "ortaöğretime geçiş sınav sistemi değişikliği fen bilimleri başarısını düşürmektedir” görüşü ortaya çıkmaktadır. Öğrencilerin fen bilimlerine yönelik başarılarının düşme nedenleri arasında en yüksek oranların sınav sisteminin belirsiz olması, motivasyonun düşmesi ve kaygının artması, sınavın zor olma durumu, sınav sisteminin sürekli değişmesi ve sınavda açık uçlu soruların olma ihtimali kategorileri yer almaktadır. Fen bilimleri başarısının yüksek olması nedenleri arasında ise gelecek sınav sisteminin zor olabilmesinden dolayı çok çalışma, s1nav sisteminin belirsiz olmasından dolayı çok çalışma, çalışan yapar düşüncesi, motivasyonum artması ve sistem değişince çalışılacak zamanın artması kategorileri yer almaktadır. Ayrıca Demirbilek ve Levent'in (2019) okul 
yöneticileri ile yaptığı çalışmada, kademeler arası geçiş ve sınav sisteminde yapılan değişikliğin eğitimin öznesi olan öğrencilerin başarısının düştüğünü ifade etmiştir. Benzer şekilde Özen ve Özenç (2017), ortaöğretime geçiş sisteminde yapılan değişiklilerin öğrencilerin başarılı olmasını törpülediği belirtmiştir. Bu sonuçlar çalışmanın bulguları ile paralellik göstermektedir.

Çalışmanın dördüncü probleminde öğrencilere "İlköğretim sekizinci s1nıf öğrencilerin fen bilimleri başarısının ölçülmesinde hangi soru türünü tercih etmektedir?" sorusu yöneltilmiş ve cevaplar alınmıştır. Cevaplar analiz edildiğinde ilköğretim sekizinci sınıf öğrencilerin çok büyük bir bölümü (\%91) çoktan seçmeli soru türünü tercih ettiği belirlenmiştir. Kuzu, Kuzu ve Gelbal'ın (2019) sekizinci sınıf öğrencileri ile yaptığı çalışmada, öğrencilerin \%77.7'si ankette yer alan ortaöğretime geçiş sınavında sadece çoktan seçmeli soruların yer almasına katılmıştır. Buna karşın çoktan seçmeli soruların yanında açık uçlu soruların yer almamasına öğrencilerin \%79.5'i katılmıştır. Bu bulgular araştırmanın bulguları ile paralellik göstermektedir. Özden, Akgün, Çinici, Sezer, Yıldız ve Taş'ın (2014) yaptıkları araştırmada merkezî sınavlarındaki fen bilimleri çoktan seçmeli sınav sorularının yarıdan fazlasının hatırlama, yetenek ve kavramlar kapsamında yoğunlaştı̆̆ını tespit etmiştir. Buna karşın fen bilimleri sorularının öğrencilerin daha üst düzey düşünme becerilerini ölçme noktasında sınırlı kaldığı tespit edilmiştir. Fakat çoktan seçmeli sorular iyi ve uygun bir şekilde hazırlanırsa bu tür maddeler bilişsel alanın bütün düzeyindeki davranışları (bilgi, kavrama, uygulama, analiz ve değerlendirme) ölçer. Ayrıca çoktan seçmeli soruların iyi hazırlanması, onları objektif ve nesnel kılmaktadır (Tekin, 2010). Fen bilimleri başarısının ölçülmesinde açık uçlu soruların sorulması öğrencilerin daha üst düzey düşünme becerileri ölçebilecektir. Bundan dolayı farklı soru tiplerinin kullanılması önerilmektedir (Ormanc1, Çepni ve Ülger, 2018).

Çalışmanın beşinci probleminde öğrencilere "ilköğretim sekizinci sınıf öğrencilerine göre ortaöğretime geçiş sınav sistemi nasıl olmalıdır?" sorusu yöneltilmiş ve cevaplar alınmıştır. Cevaplar analiz edildiğinde öğrencilerin en fazla önceki sınav sistemi gibi (TEOG) olsun, çoktan seçmeli sorulardan oluşan bir sınav olsun ve üç yanlışın bir doğruyu götürmediği sınav olsun şeklinde görüş bildirdiği belirlenmiştir. Benzer şekilde Kuzu, Kuzu ve Gelbal'ın (2019) yaptığ çalışmada ortaöğretime geçiş için günümüzde kullanılan Liselere Giriş Sınavı'nın (LGS) olumsuz yanlarının daha fazla olduğunu ve bir önceki Temel Eğitimden Ortaöğretime Geçiş (TEOG) sisteminin daha tercih 
edilebilir bir sistem olduğunu belirtmiştir. Ayrıca öğrencilerin \%84.4’ü yap1lan yanlışın doğruyu götürmemeli maddesine katılmıştır. Şad ve Şahinler (2016) önceki ortaöğretim geçiş sistemi olan TEOG sistemine ilişkin öğrenci, öğretmen ve veli görüşlerini incelemiştir. İnceleme sonucunda öğrencilerin büyük çoğunluğu yanlış soruların doğruyu götürmemesi kriterine katılmıştır. $\mathrm{Bu}$ durum araştırmanın sonuçları ile paralellik göstermektedir. Buna karşın Taşkın ve Aksoy’un (2018) fen bilimleri öğretmenleri ile yaptığ çalışmada öğretmenler, merkezî sınavlarda yanlış cevaplanan soruların doğru cevaplanan soruları etkilememe durumunu desteklememiştir. Düzeltme durumunun şans faktörünü arttıracağını ve sınavın ayırt ediciliğini düşüreceği belirtilmiştir. Benzer şekilde Ormanc1, Çepni ve Ülger'in (2018) fen bilimleri öğretmenleri ile yaptığ 1 çalışmada ortaöğretime geçiş sınav sistemindeki yanlış cevapların doğru cevapları etkilememesinin bazı aksamalara neden olacağını belirtmiştir. Güler, Arslan ve Çelik (2019) ortaöğretime geçişte bir önceki sınav sistemi olan TEOG ile günümüzde uygulanan LGS sinav sisteminin zayıf ve üstün yönlerine ilişkin öğretmen görüşlerini incelemiştir. TEOG'a kıyasla LGS'nin üstün yönlerine ilişkin öğretmen görüşleri; yanlışın doğruyu götürmesi, sorunun niteliğinin yüksek olması, farklı beceriler ölçmesi ve üst düzey beceri gerektirmesidir. Özkan ve Karataş'ın (2016) ortaokul öğrencileri ile yaptığı çalışmada öğrenciler, TEOG merkezî sınavın içerik ve uygulama açısından uyumlu olduğunu fakat sınav yüzünden kendilerini rahat ve mutlu hissedemediklerini belirtmiştir. Büyüköztürk (2016) sınavlara yapılan eleştirilerin sınavın var olup olmamasından kaynaklanmasından daha çok sınavın yapısına, kapsamına, sayısına ve yöntemine yönelik olduğunu belirtmiştir. Demir ve Yılmaz'ın (2019) sekizinci sınıf öğrencilerin velileri ile yaptığı çalışmada LGS'nin beklentilerini karşılamadığı sonucuna ulaşmıştır. Bununla birlikte velilerin adrese dayılı kayıt sisteminin olumsuz sonuçlar doğurabileceğine dair tereddütlerinin olduğunu tespit etmiştir. Ortaöğretime geçiş sınav sistemi ile ilgili veliler mazeret sınavlarının yapılmasını, sosyal etkinlik ve okul başarı puanlarının da sınav sistemine etki etmesi yönünde önerilerde bulunmuştur. Demirbilek ve Levent'in (2019) okul yöneticiler ile yaptığı çalışmada okul yöneticileri kademeler arası geçişi ve sistemin öğrenci merkezli olmasını, öğrencilere firsat eşitliği ve adalet ilkesi çevresinde yapılması gerektiğini ifade etmiştir. Fakat hedefe giderken yapılan değişiklikler, öğrenciyi temele alma ve fursat eşitliğini sağlama hedefi ile gerçekleşmediğini belirtmiştir. Aykaç ve Atar'a (2014) göre ülkemizde ortaöğretime geçiş sınav sistemleri genellikle sınav sayısının artması veya azalması şeklinde olmuş; öğrenci ilgi, 
yetenek, başarı, öğretmen görüşleri, öğrenciyi yönlendirme dikkate alınmamıştır. $\mathrm{Bu}$ sonuçlar araştırmanın bulguları ile paralellik göstermektedir. Çünkü bu araştırmanın bulgularında ilköğretim sekizinci sınıf öğrencileri, ortaöğretime geçiş sisteminin ilgi ve yetenek, mezuniyet not ortalaması, sınavsız geçiş vb. uygulamaların da olması gerektiğini belirtmiştir. Bu uygulamalar diğer dünya ülkelerin ortaöğretime geçiş sistemlerinde de görülmektedir (Atılgan, 2018). Bu şekilde bireyin her yönüyle değerlendirilmesine olanak sağlanmaktadır Ayrıca araştırmanın bulguları arasında ortaöğretim geçiş sisteminin adrese dayalı olmasını ifade eden öğrenciler de yer almaktadır. Fakat bu durum ikamet edilen çevrede zengin ve fakir sınıf ayrımına neden olabilir. Bundan dolayı sadece kademeler arası geçişte adrese dayalı bir yerleştirmenin tercih edilmemesi gerektiği önerilmektedir (Kuzu, Kuzu ve Gelbal, 2019). Bunun yanında ortaöğretim geçiş sisteminde not ortalamasının etkili olması okulundaki sürecin etkisini arttıracağından not ortalamasın etkili olması önerilmektedir (Gür, Çelik ve Coşkun, 2013). Ayrıca eğitim sisteminde meydana gelen devamlı ve plansız sistem değişiklikleri eğitimdeki niteliksel gelişmeyi engelleyecektir. Bunun yerine eğitimde sistemli ve planlı hareket edilmesi önerilmektedir (Can, 2014).

Araştırmada öğrencilerin görüşlerine göre elde edilen bulgular genel olarak değerlendirildiğinde ortaöğretime geçiş sınav sisteminde meydana gelen değişiklikler öğrencilerin fen bilimlerine yönelik kaygı, motivasyon ve başarısını olumsuz olarak etkilemektedir. İlköğretim öğrencileri fen bilimlerine yönelik soru türü olarak en fazla çoktan seçmeli soru türünü tercih etmiştir. Bunun yanında çok az bir oran da olsa sadece açık uçlu ile hem çoktan seçmeli hem de açık uçlu soru türünü tercih eden öğrencilere de rastlanmıştır. Araştırmanın bir diğer bulgusunda ortaöğretime geçiş sınav sisteminin bir önceki s1nav (TEOG) sistemi gibi olmasını isteyen öğrencilerin oranı oldukça yüksek olarak belirlenmiştir. Ayrıca öğrencilerin adaletli, objektif, yanlışın doğruyu götürmediği bir sınavı tercih ettikleri görüşü de tespit edilmiştir. Bu anlamda değişikliklerin planlı, programlı ve sistemli olması önerilmektedir. Ayrıca aday sayısının fazla ve nitelikli okul sayısının az olduğu yerlerde merkezî sınav sistemi yapılabilir. Fakat okulların nitelik bakımından bir farkı olmazsa ve devlet bütün vatandaşlarına iyi eğitim alma imkânı sağlarsa bu sınavların yapılmasına da gerek kalmayabilir. Bu durumda seçme ve yerleştirme işlemleri eleme işlemlerine göre değil öğrencilerin ilgi ve yetenekleri ile etkili rehberlik yönlendirmelerine göre yapılır. Bunun yapılabilmesi için ortaöğretime geçiş sınavının varlık gerekçelerinin ortadan kaldırılması önerilmektedir. 


\section{Kaynakça}

Atılgan, H. (2018). Transition among education levels in Turkey: Past-present and a recommended model. Ege Journal of Education, 19(1), 1-18.

Doi: $10.12984 /$ egeefd. 363268

Atila, M. E. ve Özeken, Ö. F. (2015). Temel eğitimden ortaöğretime geçiş sınavı: Fen bilimleri öğretmenleri ne düşünüyor? On Dokuz Mayıs Üniversitesi Eğitim Fakültesi Dergisi, 34(1), 124-140.

Aykaç, N. ve Atar, E. (2014, Ocak). Geçmişten günümüze ilköğretimden ortaöğretime geçiş sisteminin değerlendirilmesi. Cumhuriyet'in Kuruluşundan Günümüze Eğitimde Kademeler Arası Geçiş ve Yeni Modeller Uluslararası Kongresi’nde sunulan bildiri, Antalya.

Bakırcı, H. ve Kırıcı, M. G. (2018). Temel eğitimden ortaöğretime geçiş sınavına ve bu sınavın kaldırılmasına yönelik fen bilimleri öğretmenlerinin görüşleri. $Y Y \ddot{U}$ Ĕ̈itim Fakültesi Dergisi, 15(1), 383-416.

Başol, G. ve Zabun, E. (2014). Seviye belirleme sınavında başarının yordayıcılarının incelenmesi: Dershaneye gitme, mükemmeliyetçilik, ana-baba tutumu ve sınav kaygısı. Kuram ve Uygulamada Ĕgitim Bilimleri, 14(1), 63-87.

Batur, Z., Başar, M. ve Şaşmaz, E. (2016). Temel Eğitimden Ortaöğretime Geçiş S1navının (TEOGS) öğretmen ve öğrenci görüşlerine göre incelenmesi. Eğitim ve Insani Bilimler Dergisi: Teori ve Uygulama, 7(14), 37-53.

Büyüköztürk, Ş. (2016). Sınavlar üzerine düşünceler. Kalem Eğitim ve İnsan Bilimleri Dergisi, 6(2), 345-356.

Can, E. (2014, Nisan). Türk eğitim sisteminde nitelik: Engeller ve öneriler. I. Avrasya Eğitim Araştırmaları Kongresi'nde sunulan bildiri, İstanbul.

Delil, A. ve Yolcu Tetik, B. (2015). 8. Sinıf merkezi sınavlardaki matematik sorular1nın TIMSS-2015 bilişsel alanlarına göre analizi. CBÜ Sosyal Bilimler Dergisi, 13(4), 166-184.

Doi: $10.18026 /$ cbusos. 87313

Demir, S. B. ve Yılmaz, A. T. (2019). En iyisi bu mu? Türkiye'de yeni ortaöğretime geçiş politikasının velilerin görüşlerine göre değerlendirilmesi. Bolu Abant $\dot{I}_{z}-$ zet Baysal Üniversitesi Ĕ̈itim Fakültesi Dergisi, 19(1), 164-183.

Demirbilek, M. ve Levent, A. F. (2019). School administrators' opinions regarding the changes in the transition between grades and examination system in Turkey. Marmara University Atatürk Education Faculty Journal of Educational Sciences, 50, 57-79.

Doi: $10.15285 /$ maruaebd. 586835

Dinç, E., Uzun, C. ve Çoban, O. (2014). Eğitimde kademeler arası geçişle ilgili öğretmen görüşlerinin incelenmesi. Uşak Üniversitesi Sosyal Bilimler Dergisi, 7(3), 209-235.

Duban, N. ve Arısoy, H. (2017). 8. Sınıf öğrencilerinin temel eğitimden orta öğretime geçiş (TEOG) sınavına ilişkin algılarının metaforlar aracılığıyla incelenmesi. Kalem Eğitim ve Insan Bilimleri Dergisi, 7(1), 67-98.

Doi: 10.23863/kalem.2017.76

Erkuş, A. (2009). Davranış bilimleri için bilimsel araştırma süreci (2. baskı). Ankara: Seçkin Yayımcılık.

Eroğlu, M. ve Özbek, R. (2017, Ekim). Teacher view on the removal of the bese exam: A social network analysis. Uluslararası Akademik Araştırmalar Kongresi'nde 
sunulan bildiri, Antalya.

Güler, M., Arslan, Z. ve Çelik, D. (2019). 2018 Liselere giriş sınavına ilişkin matematik öğretmenlerinin görüşleri. YYÜ Eğitim Fakültesi Dergisi, 16(1), 337363.

Doi: $10.1017 / \mathrm{CBO} 9781107415324.004$

Gündoğdu, K., Kızıltaş, E. ve Çimen, N. (2010). Opinions of students and teachers in relation to high school entrance exam-SBS (Case of Erzurum). Elementary Education Online, 9(1), 316-330.

Gür, B. S., Çelik, Z. ve Coşkun, İ. (2013). Türkiye'de ortaöğretimin geleceği: hiyerarşi mi, eşitlik mi? Ankara: SETA Analiz. http://file.setav.org/Files/Pdf/20130802120003_ortaogretim_analiz2.pdf

Güzeller, C. (2006). Modelling the examination for secondary education (OKS) in terms of language competency in Turkish. Kastamonu Education Journal, 14(2), 403-412.

Güzeller, C. O. ve Doğru, M. (2012). Development of science anxiety scale for primary school students. Social Indicators Research, 109, 189-202.

Doi: 10.1007/s11205-011-9894-6

Heras, M. ve Ruiz-Mallén, I. (2017). Responsible research and innovation indicators for science education assessment: How to measure the impact? International Journal of Science Education, 39(18), 2482-2507.

Doi: 10.1080/09500693.2017.1392643

Kahraman, İ. (2014). Merkezi ortak sınav uygulamasının etkilerine ilişkin öğretmen görüşleri. Tunceli Üniversitesi Sosyal Bilimler Dergisi, 2(4), 53-74.

Karaca, M., Bektaş, O. ve Öner Armağan, F. (2015). 8. Sınıf öğrencilerinin merkezi sınavlarda sorulmayan fen bilimleri konularına yönelik görüşleri. Gazi Üniversitesi Gazi Eğitim Fakültesi Dergisi, 35(1), 63-86.

Karasar, N. (2009). Bilimsel araştırma yöntemi. Ankara: Nobel Yayın Dağıtım.

Kuzu, Y., Kuzu., O. ve Gelbal, S. (2019). TEOG ve LGS sistemlerinin öğrenci, öğretmen, veli ve öğretmen velilerin görüşleri açısından incelenmesi. Ahi Evran Üniversitesi Sosyal Bilimler Enstitüsü Dergisi, 5(1), 112-130.

Ocak, G., Akgül, A. ve Yıldız, S. Ş. (2010). İlköğretim öğrencilerinin Ortaöğretime Geçiş Sistemi'ne (OGES) yönelik görüşleri (Afyonkarahisar Örneği). Ahi Evran Üniversitesi Ĕgitim Fakültesi Dergisi, 11(1), 37-55.

Ormanc1, Ü., Çepni, S. ve Ülger, B. B. (2018). Science teachers' views about the transition from primary education to secondary education. Academy Journal of Educational Sciences, 2(1), 1-15.

Doi: $10.31805 /$ acjes.422031

Özden, M., Akgün, A., Çinici, A., Sezer, B., Yıldız, S. ve Taş, M. M. (2014). Merkezi sistem ortak sınav fen bilimleri sorularının Webb'in bilgi derinliği seviyelerine göre analizi. Adiyaman Üniversitesi Fen Bilimleri Dergisi, 4(2), 91-108.

Özen, E. N. ve Özenç, B. (2017). Liselere geçişte yeni sınav sistemi: Risk alanlart neler olabilir? Türkiye Ekonomi Politikaları Araştırma Vakfı değerlendirme raporu.

https:/www.tepav.org.tr/upload/files/1510240313-4.Liselere_Geciste_Yeni_Sinav_Sistemi_Risk_Alanlari_Neler_Olabilir.pdf

Özkan, E. ve Karataş, İ. H. (2016). The analysis of students' views towards the changes in transition system to the secondary schools. Journal of Research in 
Education and Teaching, 5(1), 225-234.

Özkan, M. ve Özdemir, E. M. (2014). Ortaokul 8. sınıf öğrencilerinin ve öğretmenlerinin ortaöğretime geçişte uygulanan merkezi ortak sınavlara ilişkin görüşleri. Tarih Okulu Dergisi, 7(20), 441-453.

Öztürk, F. Z. ve Aksoy, H. (2014). Temel eğitimden ortaöğretime geçiş modelinin 8. sınıf öğrenci görüşlerine göre değerlendirilmesi (Ordu İli örneği). Ondokuz Mayıs Üniversitesi Eğitim Fakültesi Dergisi, 33(2), 439-454.

Doi: 10.7822/omuefd.33.2.8

Sarıyer, Y. (2010). Ortaöğretime giriş sınavları (OKS-SBS) ve PISA sonuçları 1ş1ğında eğitimde firsat eşitliğinin değerlendirilmesi. Ahi Evran Üniversitesi Ĕgitim Fakültesi Dergisi, 11(3), 107-129.

Şad, S. N. ve Şahiner, Y. K. (2016). Temel eğitimden ortaöğretime geçiş (TEOG) sistemine ilişkin öğrenci, öğretmen ve veli görüşleri. İlkögretim Online, 15(1), 53-76.

Şahin, S., Uz-Baş, A., Sucuoğlu, H. ve Şahin Fırat, N. (2012). İlköğretim okulu öğrenci ile öğretmenlerinin ortaöğretime geçiş sistemine ilişkin görüşleri. International Journal of Human Sciences, 9(2), 847-878.

Taşkın, G. ve Aksoy, G. (2018). Students' and teachers' expectations from the transition to secondary education system in the light of TEOG system views of them. International Journal of Active Learning, 3(1), 19-43.

Tekin, H. (2010). Eğitimde ölçme ve değerlendirme. Ankara: Yargı Yayınevi.

Uğurel, I., Moralı, H. S. ve Kesgin, Ş. (2012). OKS, SBS ve TIMSS matematik sorularının 'MATH Taksonomi' çerçevesinde karşılaştırmalı analizi. Gaziantep Üniversitesi Sosyal Bilimler Dergisi, 11(2), 423-444.

Uzoğlu, M., Cengiz, E. ve Daşdemir, İ. (2013). The investigation of science and technology teachers' opinions on changes of SBS exam. Mersin University Journal of the Faculty of Education, 9(3), 77-86.

Yıldırım, A. ve Şimşek, H. (2008). Sosyal bilimlerde nitel araştırma yöntemleri (7. bask1). Ankara: Seçkin Yayıncılı.

Y1lmaz, F. (2007). Teachers' opinions about the effectiveness of science course to have students acquire scientific attitude and behavior in elementary school. Elementary Education Online, 6(1), 113-126.

Y1lmaz, H. ve Huyugüzel Çavaş, P. (2007). Reliability and validity study of the students' motivation toward science learning (SMTSL) questionnaire. Elementary Education Online, 6(3), 430-440. 